\title{
Communicable Disorder
}

National Cancer Institute

\section{Source}

National Cancer Institute. Communicable Disorder. NCI Thesaurus. Code C157825.

A disease that can be transmitted from one individual to another. 